\title{
The Leadership's Fairness and Social Skills - the Very Foundation of the Management and Functionality of an Entity
}

http://doi.org/10.21272/bel.3(3).19-24.2019

\author{
Alexandru Trifu \\ $\mathrm{PhD}$, Professor, University "Petre Andrei” of Iasi, Romania
}

\begin{abstract}
This paper is dealing with a very sensitive aspect of today's environment within an entity: the Leadership and the new challenges of the new trends, ideas, and realities regarding the human factor, both from both the viewpoint of the management and the employees. The aim of the research is to analyze the role of the Leadership within corporate activities, different from what is known today by the syntagma "politically correctness". An analysis of the literature in this domain based upon empirical observations through our own practice experiences leads to the verdict that, in this case, the corporate Leadership must be fair, as balanced as possible, empathic and pursuing the main goal(s) of the entity or organization, i.e., using skills and abilities to capacitate all employees, regardless of their gender, religion, beliefs, looks to reach the goal(s) in the benefit of corporation/organization, but also in the benefit of the employees and the environment. The methodological tools of the study are analytical and comparative methods, methods of logical generalization and scientific abstraction. Based on the analysis, it was concluded that the new approaches in theory of the firm are based on the qualities of the CEOs, how must be the behavior of the leaders, the importance of $X$ and Y Economic models and, even, the impact of social and psychological aspects on Economics. In fact, it's about the humanization of the entire management and the well-functioning of the entity is necessary to be based on human factors, but in a such manner, by training, by motivation, in order to capacitate all staff, all employees, no matters differences, to obtain the goals established and to gain benefits both for employees, management and for the firm/corporation in its relationships with the internal environment, but also with the natural and business environments. The results obtained can be useful for the owners of the enterprise and HR managers in terms of understanding the importance of leadership qualities in the successful functioning of the company and the formation of an understanding of the advisability of attracting a leader to work in various positions within the organization.
\end{abstract}

Keywords: leadership, entity, emotional intelligence, social skills, politically correctness, modus vivendi.

JEL Classification: D21, J24, J53.

Cite as: Trifu, A. (2019). The Leadership's Fairness and Social Skills - the Very Foundation of the Management and Functionality of an Entity. Business Ethics and Leadership, 3(3), 19-24. http://doi.org/10.21272/bel.3(3).19-24.2019.

(C) The Author, 2019. This article is published with open access at Sumy State University.

\section{General problem approach}

The careful analysis of the literature highlights the presence of three typical situations upon how to use the concepts of leadership and management:

The first one tends to identify the two notions. Sometimes a notion is used in the place of another, or when one of them is spoken of, the other is put in brackets. Such an operational mode appears especially in those cultures in which there are no distinctive terms in the language denoting the two realities. It is also the case of the Romanian language, where leadership and management have been translated into the term leadership.

The second typical situation lies at the opposite of the previous one, consisting in the categorical differentiation of the two notions in their opposition to a different notion.

Here are some conceptions about the distinction between leadership and management, leaders and managers.

Abraham Zaleznik (1977) seems to be the first author to draw an express line between leaders and managers. By referring to a system of criteria based upon the analysis and characterization of leaders and managers, he came to the conclusion that there are major differences between the two categories. Although the author perceives the leader and the manager as two complementary entities, there are differences in motivation, thinking, and action between them. 
Craig M. Watson (1893) by applying the procedure of the 7S (strategy, structure, system, style, staff leadership team, skills - complex abilities and shared goals) concludes that leaders are more focused on the last $4 \mathrm{~S}$ what managers focus more on the first $3 \mathrm{~S}$ : strategy, structure, and system.

A deeper analysis reveals the following delimitations of the practical significance of the two concepts discussed. Thus, managers administer; leaders innovate. The manager is a copy; the leader is the original. The managers maintain; the leaders develop. The manager focuses on systems and structure; the leader focuses on people. The manager relies on control; the leader inspires confidence. The manager has a shortterm vision; the leader has a long-term perspective. The manager asks "how?", "when?", but the leader asks "what?" and "why". The manager accepts the status quo, the leader challenges it.

The above analysis leads to the idea that the major difference between leadership and management lies in the fact that the first concept is more commonly associated with the cognitive, imaginative and anticipative plan, while the second with the action plan. The leader is the person who provides the connection with the task, but also with those who solve the established task. When the activity focuses on the task, it is said that the leader performs the synergy of efficiency. But if the focus is on people, then we talk about the group maintenance synergy. It is clear that the first situation is that which ensures the efficiency of the management act, while in the second situation the satisfaction of the group membership is achieved.

It is also the leader who prefigures the future, sets goals and action plans and the manager puts them into practice. The leader is a penetrating spirit, with analytical, strategic and multilateral thinking skills, with psychosocial abilities; the manager has operational skills and the "savoir faire" ability.

Thus, we agree that there is an enormous amount of writings and comments about management and, even the two terms - manager and leader - are often interchangeably; when we are talking about practice and operative decision-making, it's about management and speaking about skills, emotional intelligence and the power over communities, we are dealing with leaders.

A single point of view in this respect, from the managerial practice, which influences the new brand theory of Management, is that of David Hand (2017) who is pointing out that leaders are managers, but managers need to be leaders.

Also, a very interesting remark, but which needs to be tinted that of the well-known American professor, Warren Bennis, who said that Leaders are made (in a large proportion -our emphasis), they are not born (but there are also inherited features-our emphasis) (apud Bontaș, 2007).

For our purpose, a Corporate Leader is the person who gives equal attention to the community and the business and, we may complete, to the environment business within the corporation/organization (Mayhew, www.smallbusiness.chron.com).

\section{Methodology}

The research design is a survey of the empirical works in the field, especially those of the practitioners and managers, of which we synthesized the characteristics of the analyzed issue and the delimitation from the political and social syntagma of "politically correctness". Also, my own experience as a manager and attempt to be a leader were useful in this enterprise.

The below-mentioned references represent exactly the opinions of practitioners in the business field, especially from the leaders/managers point of view. This survey, combined with personal expertise and intuitions, is relevant for the issue in debate.

\section{Analyzing the problem}

\subsection{The Actual Leadership}

The leadership is in itself a special managerial process through which a person manages to determine a group of people (never 1-2 people) to act together, with competence, involvement and (we might say) with empathy, to achieve unanimously agreed goals, as well as understanding the feedback from the environment and resolving the errors made.

We will not focus upon the elements of management/leadership theory, which, even if they are not well known, are deepened by the current concepts generated by the specialists and practitioners in the field. 
For instance, Gary Vaynerchuk is trying to highlight some concepts, in fact, 4 (four) leadership strategies for someone to become a great (merely skilled) CEO (Vaynerchuk, 2019):

1. Looking out for the "Iceberg", meaning a very effective communication CEO/Leader with the employees, in order for the both parties to see and understand the dangers and to avoid them.

2. The role of the skilled CEO/Leader is that of a parent, who defends the sustainability and solvency of the entity at a macro level, even if the decisions/moves may cause some tension within the organization, i.e. at a micro-level.

3. It is necessary to create a safety feeling amongst employees. This situation, according to the second level of the Maslow Hierarchy Needs (the Safety level), leads to an emulation/motivation in business and encourages the efficiency of each and every activity.

4. The Leader works for the entity through the employees. It is necessary to understand the demands of each and every category of staff, in order to put it in the right place and to motivate it properly, in order to gain the maximum of benefits.

Furthermore, as we enter the 4th Industrial Revolution, it is mandatory to see the characteristics and skills required for the Leader/CEO of today. This new Industrial Revolution is characterized by a fusion of high technologies that is blurring the lines between the physical, digital and biological spheres. The changes produced in every industry of the world lead to deep transformations of the entire system comprising production, management, and governance.

In this context, Bernard Marr gives us a point of view about the major skills that the Leaders of this 4th Industrial Revolution need to acquire at their future workplaces, such as (Marr, 2019):

$>$ to display emotional intelligence (see more details below);

$>$ to be active;

$>$ to be accountable;

$>$ to be flexible (to meet the new requirements and to accommodate the shifting demand of employees, workplaces and devices);

$>$ to be technically savvy (to embrace the new technologies, new working platforms, in one word, to know how to deal with these new techniques and devices);

$>$ to be collaborative;

$>$ to be culturally intelligent;

$>$ to be focused (to provide the stability of the working force, to conduct the energies towards the objectives of the organization and to reveal which are the important activities and tasks for the entity).

To further draw the structure of the strategies for an actual leader, we want to also present an opinion of what an anti-CEO is perceived to be, that is the ideas of Hamdi Ulukaya, the CEO of Chobani (Roughol, 2019). In fact, the employees come before profits, as an ownership in the business:

1. To be involved in the community, to see what the needs are and what the businesses should give back to these communities.

2. To express responsibility of the businesses which may generate changes in the world and, at the same time, to express gratitude to the employees, those who make it possible, altogether with the other factors of production, the existence, and functioning of the corporation/firm/organization

3. Here comes the most interesting idea of Ulukaya, i.e. the CEOs report to the consumer, not to the board. The unity of employees, customers, community as a whole, this is the right force to develop and grow the businesses, not the public power.

To all these characteristics of a successful leader, we may add charisma, an idea developed by Bloomberg BusinessWeek's Nick Tasler (2010), and a psychological aspect, the emotional intelligence (EQ), introduced and popularized by the American psychologist Daniel Goleman (2001).

Generally speaking, the emotional intelligence includes at least three skills: the emotional awareness, i.e. the ability to identify one's own emotions; the ability to harness those emotions and apply them to the tasks to be 
Business Ethics and Leadership, Volume 3, Issue 3, 2019

ISSN (online) - 2520-6311; ISSN (print) - 2520-6761

done; the ability to manage emotions, both regulating one's own emotions, but also helping others to do the same.

In concrete terms, Daniel Goleman considers that there are 5 (five) elements which allow someone to become and grow as a Leader. These elements are the following (Goleman, 2004):

1. Self-awareness.

2. Self-regulation.

3. Motivation.

4. Empathy.

5. Social skills.

We'll insist only on the last element, which is defining (we believe) for this analysis. The aspects, which intervene, regard the modality allowing a Leader to know how to solve a conflict, how to improve communications, by any kind of device or mean and above all, how to give praise because learning how to praise others is a fine art, but well worth the effort once achieved.

\subsection{The possible liaison between Leadership and Politically correctness?}

Briefly, the concept of "politically correctness" is used to describe the language, policies, measures or actions that are intended to avoid offense or disadvantages to the members of particular/minority groups in a society/community.

As we see from this definition, the term/syntagma has a social and political character, as it is being used with a higher frequency in the last decades, even the theorists in the field affirm that this term has been introduced in the specialty language by two Marxist thinkers, Antonio Gramsci and Lukacs Georg (Holliman, 2017).

Based upon the essential features revealed by the theory (especially Daniel Goleman's) and practice in the field, our belief and opinion is that people should be allowed to talk about themselves and one should talk to them about what they care for, to make them aware of their importance in the workgroup or entity, and, on an ideological fairness basis, one should make others think like himself or herself.

The current literature devoted to the concept of "politically correctness", but to the business management/leadership segment, not to the political segment, reveals that the syntagma is elusive, although it often seems to be used as a mantra (in the same way the term "globalization" was used and it is still used) and, with which we are in agreement, the "politically correct leader (in the business field)" is an oxymoron (see Myatt, 2011).

In fact, the leader must be a correct and fair person and even the thought of acting otherwise can seriously damage the business and jeopardize the existence of the entity (i.e. of the microenvironment). In business, acting "politically correct" solves in rare cases the problem raised entirely, or in a way agreed by all parties.

It is considered that the politically correct thinking is in many cases disingenuous and, it should be remembered that this syntagma replaces one's individuality, authenticity, and one's own ideas and opinions with the rhetoric of social and political nature. The politically correct thinking is considered, however, to be a screen, utilized by the politicians, behind which the social categories of people targeted by this term are allowed to do anything they please. This is, somehow, in the true spirit of Liberalism, included in the expression modus vivendi (Gray, 2002).

The good of the humankind is too diversified to be accomplished in one lifetime. From the viewpoint of the modus vivendi, no kind of life can be the best for all of the humankind. But here, too, we are approaching the field of our interest; the field of business, the purpose of a modus vivendi cannot be to settle the conflict of values, because we need not common values, but common institutions in which different ways of life can coexist.

What about the Leadership in this format? The leadership who adopts the politically correctness way of thinking places the entity/organization in a great danger, with risks coming from the inside. This assertion of the specialists is based upon the reality that one cannot be an efficient/successful leader by subordinating the right and fair thinking to a popular one. 
There is a question asked by practitioners and researchers in the field: did the notion of "politically correctness" had indeed a favorable influence within the organization, by reducing discrimination, discomfort, isolation and even a so-called malaise? (Khilay, 2017).

The wisdom of using positive leadership means to succeed in the channeling of the efforts towards the accomplishments of the tasks and to engage different points of view.

In the leaders' cases, we deal with the individuality and afferent responsibility, action which should be done in a professional manner. The projects established train the respective team and it's the leader duty to right thinking, not popular thinking. The leader must be competent and skillful to lead others, to explain to everyone the objectives to be achieved, to make decisions, whether good or wrong, to improve the wellness of many, not of a few. And all these, no matter occupational, gender, racial, cultural, religious, disabilities, beliefs aspects of the team or staff.

\section{Conclusions}

People and, especially the Leaders/Managers, must act and conduct themselves, in business activities, in a professional manner, pursuing the interests and goals of the entity, whether it is a corporation or firm/organization. Any other discussion or attitude must be off (if possible) from the agenda of working meetings because it's about of the very-known expression (started from facts) "one person's sense of humor is another's insult".

What we are trying to highlight, above all these recommendations from the literature in the field (e.g. X secrets for business success, Y features to become a successful leader or manager, $\mathrm{Z}$ steps for reaching a high position within the entity hierarchy, etc.) is to avoid, as much as possible, the impulse for one to behave bossy (or in a reminiscent dictatorial way) similar to the dangerous expression "if you are not with me, you're against me".

How should one achieve such a goal? In a modus in rebus sense, that is a measure to apply in all actions. The correctness, the equality of gender, religion, social skills, in order to put altogether the best ideas for developing and reaching the goals of the entity, in the benefit of all parts involved in and with favorable exchanges between entity/organization and the natural/business environments. Furthermore, this business approach is in opposition with the already presented expression modus vivendi, which is applicable to a social level, where, as a synthesis, no life mode is the best for everyone.

This perception of the role of a Leader, being in unity with employees, customers and the entire community, indeed leads to a type of return on kindness, fairness and, after all, profit and true wealth.

We don't provide an exhaustive solution of the problem, but we believe that the way in which a Leader acts, thinks, his intrinsic qualities and abilities are determinant for the success of his or her enterprise.

For further researches, we think that it is recommended to use questionnaires. But, taking into account that this issue is very sensitive, subjective and of a psychological nature, the questionnaires, either from the point of view of leaders/managers, or from the point of view of employees, must be carefully conducted and based on honor, fairness, the lack of fear and of prejudices.

\section{References}

1. Bontaş, Dumitru (2007). Management general, Ed. Univ. "George Bacovia”, Bacău.

2. Goleman, Daniel (2001). Inteligența emoțională [Emotional Intelligence], Curtea Veche Publishing, București.

3. Goleman, Daniel (2004). What Makes A Leader? Harvard Business Review, January issue, www.hbr.org/archive/ viewed May 31, 2019.

4. Gray, John (2002). Cele două fețe ale liberalismului [Two Faces of Liberalism], Polirom Publishers, Iasi.

5. Hand, David (2017). Management vs. Leadership: Is there a difference? www.theceomagazine.com/business/ viewed May 27, 2019.

6. Hersey, P., Blanchard, K. H., Johnson, D. E. (2001). Management and Organizational Behavior. Leading Human Resources, 8th edition, Upper Saddle, NJ: Prentice Hill, p. 9.

7. Holliman, Alvin E. (2017). Wisdom, Leadership and Political Correctness, www.libertymagazine.org viewed June 9, 2019.

8. Khilay, Snéha (2017). How Does Political Correctness Affect Your Team? www.triningmag.com viewed June 7, 2019. 
Business Ethics and Leadership, Volume 3, Issue 3, 2019

ISSN (online) - 2520-6311; ISSN (print) - 2520-6761

9. Marr, Bernard (2019). 14 Essential Leadership Skills During The 4th Industrial Revolution, www.linkedin.com/pulse viewed May 30, 2019.

10. Mayhew, Ruth. What Is A Corporate Leader? www.smallbusiness.chron.com viewed June 1st, 2019.

11.Myatt, Mike (2011). Politically Correct Leader? Oxymoron! www.forbes.com/sites viewed May, 25, 2019.

12.Roughol, Isabelle (2019). The four responsibilities of a good leader, according to Chobani's Hamdi Ulukaya www.linkedin.com/pulse viewed June 3, 2019.

13.Tasler, Nick (2010). Five Secrets of Charismatic Leadership, Bloomberg Businessweek, www.smallbusiness.chron.com viewed June 6, 2019.

14.ToersBijns, Carl (2012). Being Politically-Correct Corrupts Leadership Skills, www.corrections.com viewed June 26, 2019.

15.Vaynerchuk, Gary (2019). What makes a great leader, www.linkedin.com/pulse viewed June 5, 2019.

16.Watson, Craig M. (1983). Leadership, Management and the Seven Keys. Business Horizons, 26(2), 8-13.

17.Zaleznik, Abraham (1977). Managers and leaders: Are they different? Harvard Business Review, MayJune, 67-78. 